\title{
Between Thomism and Roman Civil Law: The Eclectic Concept of Liberty of Bartolomé De Las Casas and his Theoretical Defence of Native Americans during the Sixteenth Century
}

Keywords: Las Casas, Native American rights, liberty, universal human rights, hatural law

DOI: $10.4312 /$ ars.11.2.281-292

\section{Introduction}

When the Spaniards discovered the relatively isolated Mesoamerican cultures, they found the existence of civilisations and communities which did not share any of their moral values. This marked an opportunity for the European intellectual world to define the limits of moral community in a multicultural world. Two ideas were advanced from contact with the American Indians: (a) the development of international law and the idea of international society (Keal, 2003, 85); and (b) the questioning of the right of advanced civilisations to dominate less advanced peoples (Keal, 2003, 87). A major player in these developments was Bartolomé de Las Casas. The Dominican bishop was perhaps one of the most passionate defenders of the Indians in the New World during the first years of the Spanish expansion in the Americas.

The study of Bartolomé de Las Casas presents numerous difficulties, and one of the most common is the lack of theoretical unity, as his numerous works present several inconsistencies during his long life. Nonetheless, the Dominican is able to create an interesting theory of inalienable rights based mainly in Roman legalistic literature and a few Thomist sources. In my opinion, this was an intelligent approach to counter the Aristotelian theory of a natural state of slavery and to defend the liberty of Native Americans. I point out that the eccentricity of Las Casas's methods is better understood when his life is examined. He did not intend to present a theory of political rights in the calm environment of the academy, but in a period of imperial expansion and theoretical turmoil. 


\section{Natural liberty and the equality of humanity}

"Without settlement there is no good conquest, and if the land is not conquered, these people (the American Indians) will not be converted." These words of Francisco López de Gomara reflected the mentality of Spaniards at the moment that their overseas empire was formed (Elliot, 1997, 149). Papal authorization gave legitimacy to the Spanish claims on America by linking the rights of the Castilian Crown over the Indies to the obligation to win the souls of the Indians to the Catholic faith (Elliot, 1997, 160). However, the Spaniards found it difficult to achieve this. In the first years of the colonization, the objective was to ship large quantities of gold to Spain, but the quantity forthcoming from the Antilles proved to be disappointing. There was, however, another desirable asset to supplement this deficiency: the Indians themselves (Elliot, 1997, 163).

The forced enslavement of Native Americans opened a debate on their legal status. According to Roman law, if the Spaniards could prove that the Indians were "barbarians" or "irrational beings" (amendes) they could legitimately enslave them. Therefore, the Spaniards needed a framework to determine the rationality of Native Americans: the only one available was the law of nature (Pagden, 1994, 155-156).

For the propagandists of the Spanish colonial endeavour, it was important to demonstrate that the American Indians had a limited rational capacity compared with that of the Europeans. This deficit explained their inability to translate natural law in their private life, and to understand their sins against nature. Furthermore, their inability to apply the mandates of the law of nature to their lives permitted the Spaniards to doubt the rational capacities of the American Indians and their ability to form commonwealths. If a political association fails to preserve morality, as appeared obvious within the Indian communities, the members would not be able to develop a civil life and display their virtues for the common good (Fernández-Santamaría, 2008, 196).

Not all of the Spanish intellectuals expressed their agreement with the Spanish empire's propositions in this regard. Arguably, the most renowned Spanish theologians of the sixteenth century doubted the validity of the conquests. The main idea of these thinkers was that natural rights existed, even for natural men. They couched their beliefs in an interpretation of the law of nature that extended to both Christians and pagans. By the law of nature, Spanish Thomist theologians indicated that formed communities must remain sovereign, despite their backwardness and religion (Behr, 2010, 76). The natural rights were held by all human beings, including the indigenous peoples of America. These claims of scholastic theologians were echoed by Bartolomé de Las Casas. 
In Las Casas's defence of Native Americans, there was, as Pennington has pointed out $(1970,151)$, an assumption common among the sixteenth century Spanish theologians: the existence of legitimate political authorities was possible in pagan societies ${ }^{1}$. Based on his personal experiences, Las Casas stated that Native Americans were capable of forming political communities before the arrival of the Spaniards, and thus were rational beings and had natural rights. As such, Native Americans were entitled to ethical treatment, mutual recognition and territorial integrity (Behr, 2010, 79).

In principle, as a Dominican, it might appear that Las Casas would resort to Thomist authorities. However, when it came to making specific references to the dignity and property of Native Americans, even if he invoked the law of nature to make clear that liberty is a natural right (Bataillon, Saint-Lu, 1976, 127), his main arguments are primarily supported by juridical literature. It appears that what Las Casas attempted "on a theoretical level, was to graft, quite consciously, a juridical theory of rights onto Aquinas's teaching on natural law" (Tierney, 1998, 276). In this way, Las Casas could justify the existence of universal and inalienable rights:

All men, all things, all jurisdictions and all regimes or dominions, as all things that belongs to men...we must at least presume, that they are free; unless the opposite is demonstrated. It is proven that from the beginning all rational creatures are born free (Digestum, De iustitia et iure, Manummissiones), because in an equal nature, God did not make one man to be slave from other, but He granted all with identical arbitrio; for this reason; one rational creature is not subordinated to another (Las Casas, 1997, 1249).

For Las Casas, liberty is a right invested in all rational creatures from the beginning. In opposition, based on Roman law, slavery may be produced by accident or fortune, but none of these cases is a natural state. In this way, Las Casas emphasized the natural and inalienable character of liberty (Tierney, 1998, 278) to deny the existence of natural slavery. It is to be noted that this crucial definition has an eclectic character, because even if the main definition (liberty as natural right) is scholastic, this is inserted between two texts taken from Roman and Canon law (Tierney, 1998, 278). The interweaving between scholastic and juridical definitions has, in my opinion, one explanation: Las Casas could not rely on Aristotle's political theory of natural slavery, and therefore had to resort to Roman law to demonstrate the unnatural existence of servitude. As the Dominican wrote:

1 "Cualesquier naciones y pueblos, por infieles que sean, poseedores de tierras y de reinos independientes, en los que habitaron desde un principio, son pueblos libres y que no reconocen fuera de sí ningún superior, excepto los suyos propios, y este superior tiene la misma potestad y los mismos derechos del príncipe supremo en sus reinos, que los que ahora posee el emperador en su reino" (Las Casas, 1997, 1255). 
Because freedom is a right invested in the men by necessity and by itself from the beginning in the rational creature; this is proven by natural right, as it is said in $1^{\text {st }}$ distinction of Ius naturale, where it reads that there exists freedom for all, and that slavery is an accidental act which takes place by sake of chance and fortune... consequently, because it is not demonstrated that someone or something is [a natural] servant, our judgment must be favourable to his freedom and by his freedom. Therefore, we must presuppose that the men are free, unless the opposite is demonstrated... as it is said in the Digestum, De usufructu and Si cuius (Las Casas, 1997, 1251).

Arguably, from this definition of liberty Las Casas advanced a Stoic-like thesis: all mankind is one, and thus all men despite their cultural differences, should receive equal treatment (Hanke, 1994, 79). Henceforth, Las Casas used a postulate of Thomism that recognized the existence of equal rights for all human beings, since they are all children of God (Beuchot, 1993, 5).

For Las Casas, a rational creature should not be ordered by or live in bondage to others. Las Casas stated that he took his definition from Aquinas, although the Italian philosopher never advanced such an idea (Tuck, 1979, 20), and this mistake might be due to an imprecise use of sources. However, as Tierney has noted, Las Casas had an impressive knowledge of the scholastic and juridical literature. If Las Casas twisted the meaning of these texts, it was because he wanted to deploy them in a different and new way: to defend the liberty of Native Americans against the discourses that affirmed their inferiority (Tierney, 1998, 280).

By arguing for the equality of humanity and condemning the enslavement of Native Americans, Las Casas used Canon rights and Roman law in new ways (Pennington, 1970, 155-156). He tacitly recognized the rights of Native Americans to political dominium and to participate in the political affairs of the Spanish communitas (Hanke, 1994, 103-104). According to Thomism, if a man has the will to exercise dominium upon his appetites, he is able to exert dominium over anything else (Brett, 2003, 14). More importantly, Las Casas claimed that if Spanish authority in the New World was to be legitimised, then it had to be voluntarily chosen by the Native Americans (Bataillon, Saint-Lu, 1976, 46).

\section{The origin of society and transference of potestas in America}

When Las Casas described the origin of civic societies, he accepted the scholastic theory of civil power. He affirmed that the need for protection forced men to enter 
in contact with others and form a community. To ensure their common survival, these first human gatherings elected leaders among them. ${ }^{2}$ This primitive process of transference of authority could be explained as a mandate of nature, but it was only when men were subjected to ius gentium that they became perfect. ${ }^{3}$

In the pre-social state, all men were free and equal, and no one was superior. Thus the origin of civil authorities resulted from the election of one person by the community. In other words, the authority of kings and princes derived from the voluntary consent of the community. ${ }^{4}$ However, even if the community has transferred its potestas it preserves its liberty, because the ruler is ultimately the legitimate recipient of political power (Skinner, 2010, 133ss). As such, while kings and princes are invested with their power by the community, and thus they can exert legitimate authority over it, the people still hold their natural liberty after this act of transference. ${ }^{5}$

Las Casas accepted this theory of the origin of the political power. For the Dominican, the transference of potestas must be free and voluntary, otherwise, the resulting rule would be considered tyrannical and unjust. It also has a universal character, and thus it is found in all political communities formed by rational men. Even the Israeli kings, said Las Casas, supposedly elected by God, received the general approval of the Israeli people. ${ }^{6}$

In interweaving the voluntary approval of the community with the legitimacy of authority, Las Casas could use this theory with a novel touch. He used it to denounce the Spanish rule in the Indies, which he considered a violent conquest followed by the enslavement of its inhabitants - and defined it as utterly illegitimate. In this way, Las

2 "Y por eso dice el Filósofo en el libro 1 de su Política... [y] San Agustín en el libro 3 De Trinitate... que en toda multitud hay algo directivo, y es por lo tanto natural que cualquier sociedad humana o vida social tenga un jefe que solicite y procure el bien común, ya que de otro modo la sociedad no se conservaría y se dispersaría...el dominio de un solo hombre sobre los demás...es de derecho natural; lo cual se confirma por el hecho por el hecho de que la naturaleza produce algunos hombres aptos para gobernar..." (Las Casas, 1997, 1237, 1243).

3 "Y así se evidencia que el dominio del hombre sobre el hombre tuvo su origen y procedencia en el derecho natural, y fue perfeccionado y conformado por el de gentes." (Las Casas, 1997, 1245).

4 "En el libre consenso del pueblo o en el acuerdo de toda la multitud tuvieron su origen y principio los reyes y gobernantes de los pueblos y la jurisdicción; luego, anteriormente no existían ni rey ni jefe, ni señor de los pueblos, y éstos eran libres, o sea que no tenían fuera de sí o sobre de sí ningún superior, ni había ningún régimen o jurisdicción ninguna que se ejerciera sobre los hombres que eran libres y que por libre decisión habían elegido dicho superior”. (Las Casas, 1997, 1253).

5 “...el juramento de fidelidad de unos hombres para con otros fueron obra del derecho secundario, según observan los doctores al comentar la ley Ex hoc iure. Quiere esto decir, que con arreglo al derecho primordial, todo, así cosas como personas, eran libres”. (Las Casas, 1997, 1253).

6 "Solamente de este modo, o sea por elección del pueblo, tuvo su origen cualquier dominio justo o jurisdicción de los reyes sobre los hombres en todo el orbe y en todas las naciones; dominio que, de otro modo, hubiese sido justo y tiránico, excepto el que fue constituido o introducido, como ocurrió con el pueblo de Israel...donde no obstante concurrió también la elección, consentimiento y aprobación de todo pueblo, por mandato o disposición de Dios" (Las Casas, 1997, 1245). 
Casas held that the American Indian princes held their positions by the law of nature and ius gentium ${ }^{7}$, unless the American Indians themselves decided freely to transfer their authority to the Spanish emperor (Tierney, 1998, 282).

Las Casas considered that the American Indians held the status of free men before the conquest. They did not owe obedience to anyone, except their princes. Las Casas thus conceded Native Americans the status of male fidei: proprietors and free men. This is a juridical definition used for another purpose: to define the use of Native American land by the Spaniards as theft, because it was taken without the consent of their legitimate owners:

We must, then, suppose this truth: all these peoples are free, and they did not owe anything before they were discovered and after they were discovered, and even today they only owe obedience to your majesty, and not of any sort, but that is owed by the free cities and towns to their universal king and lord ... it is convenient to know that the Kings of Castile did not possess anything of them, and they do not owe these people either by heritage, nor selling, nor because they had been defeated in a just war... or they were male fidei, owners of lands...but they would receive by their own will Our Majesty as supreme lord (Las Casas, 1997, 743).

If Las Casas recognized in the American Indians the natural right to elect their governors, he also granted them the right to depose their rulers when they acted against the common good. ${ }^{8}$ This application of one the principles of popular sovereignty was controversial because it assumed that the Spanish emperor could be deposed as ruler if he continued exercising domimiun usufructus over the lands of the American Indians. Oddly, to prove this point Las Casas invoked not Vitoria's theory of civil power, but the Roman law principle of quod omnes tangit (Tierney, 1998, 284).

In the case of the communal lands, such as those of Native Americans, Las Casas held that when property is shared in common, all the members of this group must be consulted in matters that affect these assets. More interestingly, Las Casas found a political use of this principle: Native Americans must decide as group to accept the Spanish rule and its burdens.

$7 \quad$ "Cualesquier naciones y pueblos, por infieles que sean, poseedores de tierras y de reinos independientes, en los que habitaron desde un principio, son pueblos libres y que no reconocen fuera de sí ningún superior, excepto los suyos propios, y este superior tienen la misma potestad y los mismos derechos del príncipe supremo en sus reinos, que los que ahora posee el emperador en su reino" (Las Casas, 1997, 1255).

8 "...se colige que si siempre y en todo lugar es justo que el pueblo que antepone el provecho e utilidad privada y particular a la de la república, se le pueda quitar el poder o autoridad de criar reyes o gobernadores que lo rijan, por aquel que pueda mucho, el cual se ha de entender poder de derecho, no de hecho sólo...La cual la autoridad y poder de elegir reyes compete a cualquiera pueblo libre, de ley natural y de derecho de gentes" (Las Casas, 1997, 1003). 
As Tierney notes, Las Casas gave this argument a more radical turn. Based on Canon literature, Las Casas realized that a group of persons could possess a right as a corporate whole or as single individuals. In the first case, only the majority suffice to accept a determinate right (Tierney, 1998, 285). However, in cases where the rights and liberty of individuals are affected - as in those of native Indian kings and other lesser persons -if the majority of Indians accepted the Spanish rule then the whole population had to be summoned to consent. This goes further, because Las Casas held that the consent of the majority could not prejudice the liberty of individuals and minorities. ${ }^{9}$

Las Casas's aim was for the American Indian caciques to hold the authority in their communities, but they also recognized the authority of the Spanish emperor. Las Casas hoped to create a federation of Christian kingdoms in the Americas in which the Spanish emperor acted primus inter pares. The Indian princes would be inferior in authority to the emperor, but their sovereignty would remain almost intact over their lands. ${ }^{10}$

For Las Casas, it was very important to demonstrate the validity of the papal grants to Spain. When Las Casas analysed the papal bull he realized that Native Americans were not accused of being enemies of the Christian faith, and they also did not commit other crimes which merited the loss of dominium. ${ }^{11}$ In fact, the papal bull only assigned duties to Spain in the newly discovered land. Even if these decrees justified the Spanish presence in the Americas, they did not justify removing the political power of legitimate kings (Bataillon, Saint-Lu, 1976, 13).

As Saint-Lu has pointed out, Las Casas did not deny the validity of the papal bull as a title of assignation, but he thought its aims had been misunderstood. Thus, for Las Casas, it was necessary to restate the true significance of the bull (Bataillon, Saint-Lu,

9 "Porque a las personas no se les puede tomar su hacienda justamente, sin culpa suya, contra su voluntad, mucho menos deteriorar y abatir su estado y usurpar su libertad, que a todo precio es incomparable...mucho menos se puede donar y traspasar los vasallos a ningún señor particular, como... el señorío paternal...no se funda en el consentimiento del hijo, sino en la fuerza y la naturaleza, el del rey sobre sus vasallos, que es más moderno y de iure gentium, y se funda en el voluntario consentimiento de los súbditos” (Las Casas, 1997, 747).

10 “...el soberado principado imperial e universal de los reyes de Castilla se compadece tener los reyes y señores naturales de los Indios sobre sus pueblos e reinos su jurisdicción, administración, derecho y señoríos...los reyes y señores naturales de aquel orbe no pierden su señorío sin alguna culpa nueva... con ponerles por superior a quien reconozcan, un cristiano príncipe...la jurisdicción e potestad que absolutamente poseían se les haya restringido. Luego sólo en aquella restricción, regulación o limitación, y en lo que ella concerniente, dejan de ser lo que eran antes, libres príncipes, pero en cuanto lo demás, en ninguna cosa se les perjudica” (Las Casas, 1997, 1207).

11 “...la donación...que hizo e hiciese a los reyes cristianos la Sede Apostólica...no se funda sobre tengan los tales infieles nuestros reinos e tierras...ni se funda sobre injuria ni daño que nos hayan hecho...ni porque nos impugnen, infesten o molesten, ni que sean enemigos de nuestra fe...ni porque ensucien con sus vicios y ceremonias nuestras tierras, porque no ensucian sino las suyas" (Las Casas, 1997, 1041, 1043). 
1976, 15). He did not separate the political objectives of Spain in the Americas with its religious duties (Zavala, 1993b, 180). He was willing to accept that conversion into the Catholic faith could be understood as an act of transference of power. The bull thus constituted a legal transaction in habitu, but it would come into force only when the American Indians freely accepted the Christian faith (Zavala, 1993a, 117). However, Las Casas noted that this act could not undermine the natural liberty of the American Indians (Saint-Lu, 1982, 16).

In order to justify the sovereignty of the Spanish kings, Las Casas resorted to Canon rights (Pennington, 1970, 156). They thus had the right to exert their authority in the New World id est, ob interpositam causam, ${ }^{12}$ because this authority was assigned by the Pope. ${ }^{13}$ Las Casas resolved this issue by appealing to a formula used in ecclesiastical elections (Pennington, 1970, 157), and invoked the division between ius ad rem and ius in re). When a magistrate had been elected to an office he acquired the preferential claims of his office ius ad rem, but he did not acquire right to exercise the de facto powers in office, unless he was confirmed ius in re. The Spanish emperor had papal permission to rule over the Indies, but he had to be confirmed by the American Indians ius in re, which had to be done through a free act of approval, which for Las Casas could be the acceptance of the Catholic faith (Tierney, 1998, 283). In other words, when Native Americans were fully Christianised, then the Spanish kings could exert some form of "contentious jurisdiction" over them. ${ }^{14}$ As Las Casas wrote:

It is after the kings and princes of those kingdoms receive baptism and become Christians, when it enters in effect the mentioned apostolic concession and donation; the Spanish kings of Castile are the source of all temporal jurisdiction; since that moment, in a new manner, it derives from them all jurisdictions and power that the natural kings and princes has, or had, over their towns and peoples in the Indies (Las Casas, 1997, 1227).

12 "Los reyes de Castilla y León tienen justísimo título al imperio soberano e universal o alto de todo el orbe de las que llamamos Océanas Indias...por virtud de la autoridad, concesión y donación, no simple y mera, sino nodal id est, ob interpositam causam, que la Sancta Sede apostólica interpuso y les hizo. Y este no es otro, el fundamento jurídico y substancial donde estriba y está colocado su título" (Las Casas, 1997, 925).

13 “...conviene saber, que el Sumo Pontífice sea sucesor de San Pedro y vicario de Cristo, Hijo de Dios vivo, tenga plenísimo poder en la tierra sobre todo el mundo, al menos sobre todos los fieles que recibieron agua del santo bautismo" (Las Casas, “Tratado comprobatorio del imperio soberano", 927).

14 “...concedemos que los reyes de Castilla y León tienen sobre todas aquellas indianas gentes infieles, mientras infieles fueren, su poder y potestad en habito... mientras son infieles no pueden ser forzados ni usarse con ellos la jurisdicción contenciosa o forzosa en actu, como estén fuera totalmente de la Iglesia y, por consiguiente, no sean súbditos de ella ni de algún miembro suyo...Pero después de que la fe y el bautismo hayan recibido en $a c t u$, y pueden usar y ejercer la jurisdicción contenciosa, como en sus súbditos en todo caso y causa...luego entretanto que son infieles y no se convierten, regularmente la Sede Apostólica debe usar con ellos la jurisdicción voluntaria." (Las Casas, 1997, $1147,1149)$. 
For Las Casas, this knowledge is grasped by a voluntary act of will; the act of understanding any knowledge requires some freedom. Before renouncing their indigenous faiths, the Indians must be convinced with good reasons to accept Christianity; otherwise, a forced conversion should be considered false. After Native Americans were fully Christianised and accepted into the Spanish community, they held their natural liberty and other rights intact, because these rights were fixed and immutable. ${ }^{15}$

\section{Conclusion}

Las Casas's defence of the natural liberty of the American Indians was done in three fields: the propagandistic, theological and juridical (Bataillon, 1976, 341). Even if these arguments lacked uniformity, they represented among the first in favour of universal rights (Tierney, 1998, 281). However, it is important to note that Las Casas always showed a certain caution with regard to pure theoretical dissertations (Bataillon, 1976, 23). For the Dominican, personal experience had more weight when it came to understanding the reality of the New World (Bataillon, 1976, 49). Las Casas allowed these theoretical inconsistencies, since he acted as a zealous lawyer against the enemies of Native Americans. In other words, in his disputes, Las Casas was impelled to use the most appropriate language to make his voice heard, even if this led to many incongruities.

Las Casas paired Canon and Roman law with arguments common to the School of Salamanca, an eclecticism that makes him an author difficult to define. For scholars such as Beuchot $(1993,5)$ and Pagden $(1994,134)$ the Dominican is a representative of Spanish Thomism. However, his most interesting writings are derived from juridical textbooks. It seems that in the heat of his numerous discussions, Las Casas did not attempt to make coherent use of his arguments. As a result, in his arguments Thomist theses get mixed with Roman and humanist authorities, using a rhetorical tone.

In conclusion, by protesting against Indian slavery in the most passionate terms, Las Casas could reach a wider audience and, in this way, attempt a reformation of the Spanish colonial system (Bataillon, Saint-Lu, 1976, 24). Nevertheless, it was the theological and legal culture that allowed Las Casas to attempt real changes in favour of Native Americans. This cultural baggage permitted him to propose a universal theory of rights and to advance the obligations of the Spaniards in the New World (Bataillon, Saint-Lu, 1976, 21).

15 “...aquellas gentes todas y aquellos pueblos de aquel orbe [América]; la libertad no pierden por admitir y por tener a Vuestra Majestad...Esta intención tuvo la cristianísima señora reina doña Isabel...que los indios fuesen tratados como personas libres que eran...Y en Burgos...se determinó y declaró que eran libres y debían ser tratados como libres” Las Casas, 1997, 743). 


\section{Bibliography}

Bataillon, M., Estudios sobre Bartolomé de las Casas, Barcelona 1976.

Bataillon, M., Saint-Lu, A., El Padre Las Casas y la Defensa de los Indios, Barcelona 1976.

Behr, H., A History of International Political History: Ontologies of the International, London 2010.

Beutchot, M., El fundamento de los derechos humanos en Bartolomé de las Casas, ARETE V/1-2, pp. 5-13.

Brett, A., Liberty, Right and Nature: Individual Right in Later Scholastic Thought, Cambridge 2003.

Casas, B., Tratados (vol. 2), México D. F. 1997.

Elliot, J. H., The Spanish conquest and the settlement of America, in: The Cambridge History of Latin America. Colonial America (vol. 1) (ed. Bethell, L.) Cambridge 1997, pp.146-206.

Fernández-Santamaria, J. A., The State, War and Peace, Cambridge 2008.

Hanke, L., All Mankind Is One: A Study of the Disputation Between Bartolome De Las Casas and Juan Gines De Sepulveda in 1550 on the Religious and Intellectual Capacity of the American Indians, DeKalb, Illinois 1994.

Keal, P., European Conquest and the Rights of Indigenous Peoples: The Moral Backwardness of International Society, Cambridge 1990.

Pagden, A., The Uncertainties of Empire, London 1994.

Pennington, K. J., Bartolomé de Las Casas and the tradition of Medieval Law, Church History 39/2, pp. 149-161.

Saint-Lu, A., Las Casas Indigéniste: étude sur la vie et oeuvre du défenseur des Indiens, Paris 1982.

Tierney, B., The Idea of Natural Rights, Atlanta 1998.

Tuck, R., Natural Right Theories: Their Origin and Their Development, Cambridge 1990.

Zavala, S., Por la senda hispana de la libertad, México D. F. 1993a.

Zavala, S., La filosofía política en la conquista de América, México D. F. 1993b. 
Manuel Méndez Alonzo

\section{Med tomizmom in rimskim civilnim pravom: eklektični koncept svobode Bartoloméja de las Casasa in njegov teoretski zagovor staroselcev $v$ 16. stoletju}

Ključne besede: Las Casas, pravice staroselcev, svoboda, splošne človekove pravice, naravno pravo

$\mathrm{V}$ prispevku avtor predstavi teorijo o naravnih pravicah in svobodi Bartoloméja de las Casasa. Meni, da Las Casasove teoretske osnove najdemo v pravnih besedilih, ki jih je dopolnil le s tomističnimi viri. Avtor pokaže, da so Las Casasove navidezne nedoslednosti delovale kot sredstvo za povečevanje učinkovitosti diskurza proti tistim, ki so zagovarjali zasužnjevanje staroselcev. Eklekticizem pa je Las Casasu omogočil, da s posluževanjem besedil in terminov kanonskega prava oblikuje izvirno teorijo o civilni oblasti in svobodi. 


\section{Alonzo Manuel Méndez \\ Between Thomism and Roman Civil Law: The Eclectic Concept of Liberty of Bartolomé De Las Casas and His Theoretical Defence of Native Americans During the Sixteenth Century}

Keywords: Las Casas, Native American rights, Liberty, Universal Human rights, Natural law

In this paper I present the theory of natural rights and liberty of Bartolomé de Las Casas. I hold that the theoretical foundation of Las Casas is found in juridical texts, only complemented by Thomist authorities. I show that the apparent inconsistencies were a means to make his discourse more effective against those who defended the enslavement of Native Americans. Finally, this eclecticism enabled Las Casas to create an original theory of civil power and liberty by using Canon law texts and terms. 